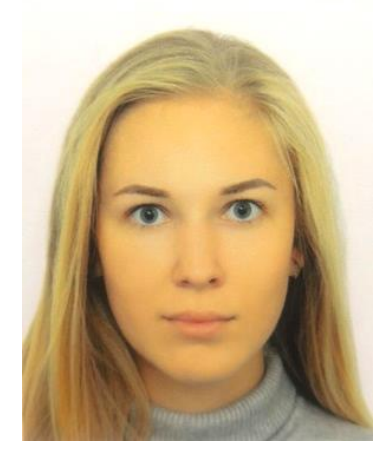

\section{JUSTIFICATION OF THE FUNCTIONAL MARMALADE RECIPE}

\author{
A. V. Stroshkova, student, \\ e-mail: stroshkova.nastya@gmail.com \\ Kaliningrad State Technical University \\ I. M. Titova, PhD, Associate Professor, \\ e-mail: inna.titova@klgtu.ru \\ Kaliningrad State Technical University \\ I. P. Massalina, \\ $\mathrm{PhD}$, Associate Professor, \\ e-mail: inga.massalina@klgtu.ru \\ Kaliningrad State Technical University
}

The article analyzes the mass fraction of sugar in the composition of the most common types of marmalade in retail chains. The hypothesis of the relationship between the statistics of childhood obesity in Russia and the increase in the consumption of "hidden" sugars is presented. The article substantiates the relevance of introducing healthy sweets into the diet of children. The results of a patent search and laboratory study of the sugar content in industrial marmalade by capillary electrophoresis are presented. A computer model of the marmalade recipe with a low sugar content and high nutritional value was obtained.

Kew words: childhood obesity, excessive sugar consumption, functional product, marmalade, computer modeling

\title{
INTRODUCTION
}

The problem of excessive sugar consumption is becoming more and more urgent for Russia. Store shelves are now filled with all sorts of sweets, in the vast majority of which the amount of sugar is not defined by regulatory documents, which allows manufacturers to add it in incredible quantities. Therefore, the consumer often does not understand how much sugar he receives and what is the cause of health problems, such as diabetes, obesity, and cardiovascular diseases.

According to the World Health Organization (WHO), childhood obesity is associated with risk factors for cardiovascular diseases, type 2 diabetes, orthopedic problems, mental disorders, as well as poor school performance and low self-esteem [1]. In addition, current research shows that obese people are $48 \%$ more likely to die from infection with the novel coronavirus infection COVID-19 [2].

The main cause of obesity is uncontrolled sugar consumption by both adults and children. In addition to refined sugars that come with sweets, the daily diet is dominated by the proportion of products containing the so-called "hidden" sugar. Often, in many processed products, such as sausages, sauces and fast food, sugar is used as a flavor enhancer. The proportion of sugar in such products can reach $20 \%$. Therefore, by consuming the usual set of products, even without including sweets in the diet, you can easily exceed the norm of sugar consumption set by experts of the WHO (World Health Organization) that is $50 \mathrm{~g}$ per day per person with a normal weight, and for children under 18 years old and the elderly $-24 \mathrm{~g}$ [1]. 
Besides that, the recent increase in the number of diseases associated with the lack of micronutrients, such as calcium and iodine, is of the particular concern [2]. The lack of calcium in the diet leads to a delay in the growth and development of children, and iodine - to serious problems with the thyroid gland.

According to the World Health Organization, sugar "washes out" the already insignificant amount of calcium and iodine that enters the body with food. Thus, it can be concluded that excessive sugar consumption has a direct impact on the lack of nutrients in the human body. This is especially urgent for school-age children [1].

The compensation of this nutrients can be due to their additional introduction in the form of biologically active additives in food products. As such a product, it is proposed to use jellyfruit marmalade with a reduced sugar content for previously justified reasons [3].

\section{THE OBJECT OF THE RESEARCH}

As an object of research on the sugar content, a popular jelly enriched with a vitamin complex, with the trade name "BONDI Begemotik", was chosen. Also, for comparison, jellyfruit marmalade with natural fruit puree "Marmaladnaya Skazka" was chosen.

\section{THE PURPOSE AND TASKS OF THE RESEARCH}

The aim of the research is to develop an optimized recipe for marmalade with a reduced sugar content and increased nutritional value using mathematical modeling methods.

In the course of the study, the following tasks will be solved:

- perform a patent search for direct analogues;

- determine the mass fraction of sugar in popular marmalade using laboratory tests;

- model the recipe for functional marmalade using information technology.

\section{METHODS OF THE RESEARCH}

To assess the sugar content in marmalade, the method of capillary electrophoresis on the device "KAPEL-105M" was used. The study was conducted according to the method M 04-922020. Indirect detection of components was performed at a wavelength of $230 \mathrm{~nm}$. [4]. The determination of dry substances in marmalade was carried out according to GOST 5900-2014 [5].

As a model for mathematical design, the recipe of jelly-fruit marmalade containing fruit puree, sugar, pectin, citric acid and biologically active additives "Oyster calcium citrate" of the company "PANTIKA" and the biocomplex "Artemia Gold" of the company "BIO Building" was chosen. These supplements are natural and easily digestible, have a unique composition and contain the elements that are necessary for the child's body.

The simulation of the recipe was carried out by computer modeling using the Excel program. [6]

Patent research was conducted in order to select the most effective (commercially significant) scientific and technical achievements using the patent search method in the information search system on the FIPS website [7].

\section{RESULTS OF THE RESEARCH}

The conducted patent search showed that jelly and chewing marmalade are actively used as a functional product. There are several patents protecting the technology of application or the origin of various biologically active additives, which are either plant extracts or products of hydrobiont processing. Among the most interesting additives are:

* seabuckthorn pomace, rich in B vitamins; [8]

* collection of medicinal herbs "Arfazetin", which has hypoglycemic properties; [9]

* extract from flax seeds; [10]

* "Lamifaren" biogel from brown seaweed; [11]

* ginkgo leaf extract and succinic acid, etc. [12] 
Technical solutions protected by these patents are used by food industry enterprises that produce marmalade enriched with nutrients, which proves the interest of customers and the increased demand for products of functional value.

The results of the sugar content studies in the considered samples of industrial marmalade are shown in Table 1 and Figure.

Table 1 - The mass fraction of sugar in terms of dry matter

\begin{tabular}{|l|c|}
\hline \multicolumn{1}{|c|}{ The trade name of marmalade } & $\begin{array}{c}\text { The mass fraction of sugar in terms of dry } \\
\text { matter, } \%\end{array}$ \\
\hline Jelly "BONDI Begemotik" & 54 \\
\hline Marmalade "Marmaladnaya Skazka" & 47 \\
\hline
\end{tabular}

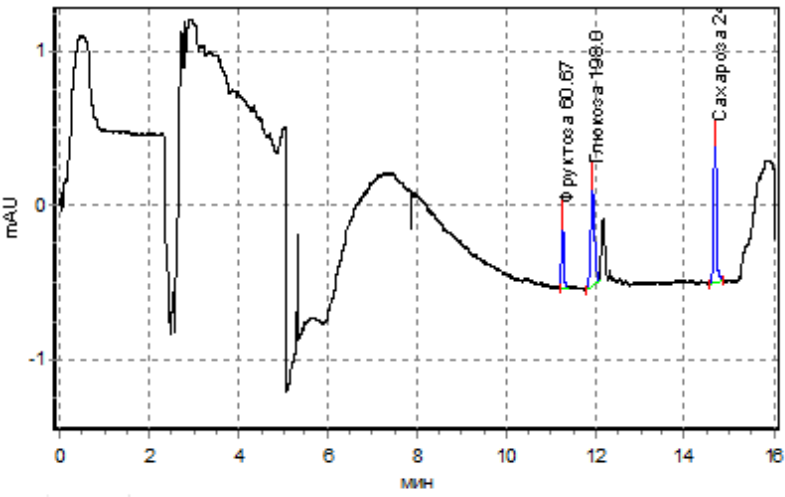

a)

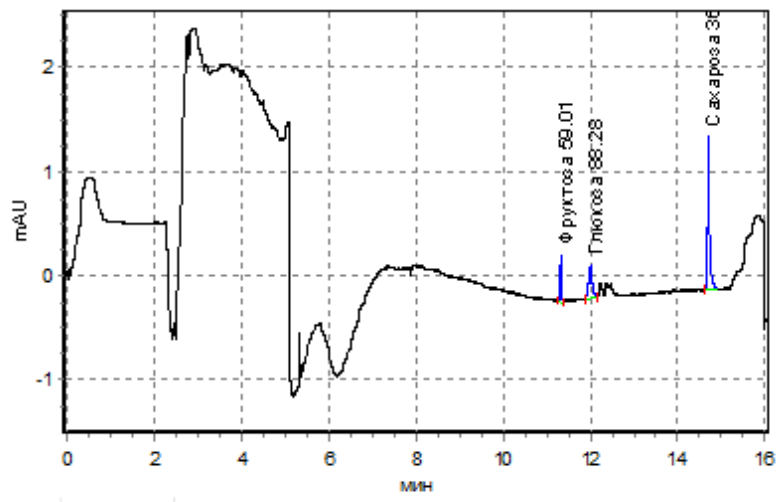

6)

Figure - Electrophoregrams of the marmalade samples: a) Jelly "BONDI Begemotik";

b) Marmalade "Marmaladnaya Skazka"

The study showed that the sugar content of the popular marmalade is about $50 \%$. That is, this product, opposite to the opinions of consumers and advertising, is not dietary and heathy. On the contrary, eating a small amount of such marmalade, you can easily exceed the previously mentioned norm of daily sugar consumption.

Taking into account the results of the conducted research, a balanced recipe for functional marmalade was developed. By definition, a natural functional food product is a product consumed in a processed form, containing in its composition natural functional food ingredients of the original plant raw materials in an amount that is at least $15 \%$ of the daily requirement in one serving of the product [13].

The daily requirement for calcium for children under 18 years old is $1200 \mathrm{mg}$, and iodine - $150 \mathrm{mcg}$. [14]. Thus, one serving of marmalade, which is $50 \mathrm{~g}$ per day, should contain at least $180 \mathrm{mg}$ of calcium and $22.5 \mathrm{mcg}$ of iodine.

The resulting recipe for functional marmalade is presented in Table 2.

Table 2 - The results of modeling the marmalade recipe using Excel

\begin{tabular}{|l|c|}
\hline \multicolumn{1}{|c|}{ Ingredients } & The mass fraction, \% \\
\hline Fruit puree & 60 \\
\hline Sugar & 15 \\
\hline Pectin & 1 \\
\hline Glucose syrup & 10 \\
\hline Lemon acid & 1,5 \\
\hline Calcium Citrate & 0,6 \\
\hline Biocomplex "Artemia Gold» & 0,4 \\
\hline Energy value, kcal & 142,1 \\
\hline
\end{tabular}




\section{CONCLUSION}

In the course of the work, the relevance of the modernization of the marmalade recipe in terms of enriching it with biologically active additives containing calcium and iodine was noted and proved.

The conducted patent search confirmed the relevance of using marmalade as a functional product.

The study of the sugar content in marmalade of popular brands was conducted. The analysis was carried out using capillary electrophoresis and showed that industrial marmalade contains about $50 \%$ sugar in terms of dry matter.

On the basis of the conducted studies, the formulation of functional marmalade was modeled according to the selected factors. The optimal values of the parameters of the mass fraction of sugar and dietary supplements were selected, which amounted to 15 and $1 \%$ of the total weight of the product, respectively.

\section{LIST OF REFERENCES}

1. Guidelines for sugar consumption by adults and children. / World health organization. [Electronic resource].

URL: https://www.who.int/nutrition/publications/guidelines/sugars_intake/ru/ Date of request: 25.11.2020

2. The Ministry of health named the regions suffering from obesity. / RBC [Electronic resource]. URL: https://www.rbc.ru/society/24/07/2018/5b519ee49a7947f2d4d7fa9b Date of request: 25.11 .2020

3. Stroshkova A. V. the Development of formulations of candy increased functionality [Electronic resource] // Bulletin of youth science of KSTU: electron. scientific journal 2019. № 4. URL: http://vestnikmolnauki.ru/4-21 Date of request: 25.11.2020

4. Method M 04-92-2020. Determination of fructose, glucose, lactose and sucrose in food, feed and food additives. [Electronic resource]. - URL: https://www.lumex.ru/metodics/20ARU03.12.19-2_sugars-food.pdf Date of request: 17.10.2020

5. GOST 5900-2014 Confectionery Products. Methods for determining moisture and dry matter. [Electronic resource]. - URL: http://www.garant.ru Date of request: 17.10.2020

6. Lisin P. A. Computer modeling of production processes in the food industry: textbook. stipend. Saint Petersburg: LAN, 2016. 256 p.

7. Search engine. / FIPS. [Electronic resource]. URL: https://www.fips.ru/iiss / Date of request: 25.11 .2020

8. Russian Patent No. 2043035, 10.09.1995. Jelly marmalade and how to get it// The Patent Of Russia № 2043035. 1995. / L. I. Karnaushenko, A. D. Claveles, L. G. Zhivoluk, O. Chimeddorj

9. Russian patent No. 2227 631, 10.10.2002. Method of manufacturing jelly marmalade // Patent of Russia № 2227 631. 2002. / Donchenko L. V., Rodionova L. I. Kvasenkov, O. I., I. S. Imagina

10. Russian patent No. 2558 206, 01.04.2014. Jelly marmalade functional purpose // Russian patent No. 2,558,206. 2014. / Tarasenko N. A., Belyaeva Yu. a., Kurakina A. N.

11. Russian Patent No. 2670173, 18.10.2018. Marmalade with lamifaren// Patent Of Russia No. 2670173. 2018. / Volkov S. M., Nureev D. F., Kudashkina N. V., Khasanova S. R., Gerasimova L. P., Usmanova I. N., Kabirova M. F., Usmanov I. R., Shakirova F. A.

12. Russian Patent No. 2616786, 18.04.2017. Marmalade prophylactic purposes// Russian patent No. 2616786. 2017. / Ezhova K. S., Maksimenko D. N., Tarasenko N. A.

13. GOST R 52349-2005 Food Products. Functional food products. Terms and definitions. [Electronic resource]. - URL: http://docs.cntd.ru/document/1200039951 Date of access: 19.11 .2020

14. MR 2.3.1.2432-08 Norms of physiological needs in energy and food substances for various groups of the population of the Russian Federation. [Electronic resource]. - URL: 
https://www.rospotrebnadzor.ru/documents/details.php?ELEMENT_ID=458 3 Date of request: 25.11.2020

\title{
ОБОСНОВАНИЕ РЕЦЕПТУРЫ ЖЕЛЕЙНО-ФРУКТОВОГО МАРМЕЛАДА
}

\author{
А. В. Строшкова, студентка, \\ e-mail: stroshkova.nastya@gmail.com \\ И. М. Титова, канд. техн. наук, доц., \\ зав. кафедрой технологии продуктов питания, \\ e-mail: inna.titova@klgtu.ru \\ И.П. Массалина, канд. фил. наук, доц. \\ e-mail: inga.massalina@klgtu.ru \\ ФГБОУ ВО «Калининградский государственный \\ технический университет»
}

В статье приводится анализ массовой доли сахара в составе наиболее распространенных в торговых сетях видов мармелада. Представлена гипотеза взаимосвязи статистики детского ожирения и заболеваний, связанных с нутриентной недостаточностью, в России и увеличения потребления «скрытых» сахаров. Дано обоснование актуальности введения полезных сладостей в рацион питания школьников. Приводятся результаты патентного поиска и лабораторного исследования содержания сахара в промышленном мармеладе методом капиллярного электрофореза. Получена компьютерная модель рецептуры мармелада с пониженным содержанием сахара и повышенной пищевой ценностью.

Ключевые слова: детское ожирение, избыточное потребление сахара, функииональный продукт, мармелад, компьютерное моделирование. 